\title{
RELATIONSHIP BETWEEN MOBILE PHONE USES WITH AN ANXIETY AMONG STUDENTS IN UNIVERSITI TEKNOLOGI MARA, SEREMBAN
}

\author{
RUQAYYAH SOLEHAH ABU HANIPAH, NOR AIZAL AKMAL ROHAIZAD* AND \\ MOHD IZZAMUDDIN NADIN
}

Faculty of Business, Economics and Social Development, Universiti Malaysia Terengganu, 21030 Kuala Nerus, Malaysia

*Corresponding author:aizal@umt.edu.my

http://doi.org/10.46754/umtjur.2021.01.007

\begin{abstract}
There is sufficient evidence regarding the potential risk of mobile phone use on anxiety. Therefore, the aim of research was to examine the relationship between mobile phone use and anxiety among students from two faculties in University TeknologI Mara (UiTM) Seremban. This cross-sectional study included 317 students of both genders. The sampling method was measured using proportionate stratified sampling. Level of mobile phone use was measured using Problem Use Mobile Phone (PUMP) Scale and level of an anxiety was measured using Beck Anxiety Inventory (BEI) Scale. In Malaysia, there are very small amount who made this research. The finding of this study showed that majority respondents are at normal level for mobile phone use. Pearson correlation result shows there was significant correlation between mobile phone use with an anxiety among students. This study indicates the important mobile phone use toward an anxiety among university students.
\end{abstract}

Keywords: Mobile phone use, anxiety

\section{Introduction}

Mobile phone use has been hugely accepted by Malaysian especially amongst students. Gadgets is something that students need in their daily life to be able to communicate with other people, making photo and video and so on. Computers, mobile phone, tablets are the examples of gadgets that being used nowadays. In recent years, mobile phones have become pervasively used globally (Pew Research Center, 2014). Smartphones are getting more popular as its ability to access the internet. This function has become one of the factors that attract teenagers to use it.

Research done by Long et al. (2016) found that problematic towards mobile phone use among undergraduates in China have reported higher levels than other Asian samples with similar cultural backgrounds. Based on the past research by Igarashi et al. (2005); Matsuda, (2000), mobile phones are spreading in popularity; young people, especially, increase their social communication frequency and expand their opportunities for making social relationships

Problematic mobile phone use is associated with health hazards, such as texting while driving, leading to injury and death (Cazzulino et al., 2014), and types of psychopathology, including anxiety and depression (Demirci et al., 2015; Kim et al., 2015). The youth becomes the largest consumer of such devices and services, which in turn makes them addicted (Muduli, 2014). According Cheever et al. (2014), the higher use of mobile phone, so that will be increasing an anxiety.

In addition to "problematic smartphone use," other terms that have been used to describe this construct regarding a smartphone include "addiction," "excessive use," "compulsive use," and "compensatory use" (Kardefelt-Winther, 2014; Widyanto \& Griffiths, 2006). Mobile phone phobia 
is also called Nomophobia and it is defined as having fear of having no contact with mobile phone (Iqbal et al., 2017). We can conclude mobile phone use also can relate with mental health and anxiety.

Anxiety is one component of the mental health and defined as a psychological and physiological state characterized by cognitive, somatic, emotional, and behavioural components(El-Sayed Desouky \& Abu -Zaid, 2020). These components combine to create an unpleasant feeling that is typically associated with uneasiness, fear, or worry. Anxiety is a generalized mood condition that occurs without an identifiable triggering stimulus (Seligmen, Walker \& Rosenhan, 2001).

Although mobile phone brings a lot of benefit towards the user, it also has negative influence. Jee Hyun et al. (2008) says that the research towards 595 students found that excessive use of mobile phone cause depression, high anxiety, and low selfesteem.

There are three objectives of the research:

1.3.1 To identify level of mobile phone use among students in UiTM Seremban.

1.3.2 To identify level of an anxiety among students in UiTM Seremban.

1.3.3 To examine the relationship between mobile phone use and an anxiety among students in UiTM Seremban.

\section{Methodology}

\section{Participants}

The UiTM Seremban student were the target population of this study. 317 students were randomly selected from two faculties which are Faculty of Sports Science and
Recreation and Faculty of Computer Science and Mathematics. Participants for the present study were selected using proportionate stratified sampling. In total $213(67.2 \%)$ of the participants are female, while the remaining $104(32.8 \%)$ are males.

\section{Methods}

The PUMP includes 20 items, five-point Likert-type self-rating scale developed by Merlo, Stone and Bibbley (2013). The 20 items are grouped into scores with the ten following components: tolerance, withdrawal, craving, social or interpersonal problems due to mobile phone usage, knowledge about physical hazard due to the usage of mobile phones, physical and psychological problems, using for longer time than intended, great deal of time spent, activities given up or reduced and failure fulfilling role obligations (Schroeder, Bailey, Whitmer \& Sims, 2017). The Cronbach's alpha of the PUMP Scale is 0.94 and this is considered high level internal consistency for this research according of Tavakol and Dennick (2011). The options on these scales range from 1 (strongly disagree) to 5 (strongly agree). The higher scores indicate more usage of mobile phones and more problematic use (Waheed et al., 2017). The total score of scale can vary between 20 to 100 .

An anxiety was assessed using the BAI Scale (Beck et al., 1998). It consists of 21 self-rated questions with four-point Likerttype self-rating scale. The Cronbach's alpha of the BAI Scale is 0.92 and this is consider high level internal consistency for this research according of Tavakol and Dennick (2011). The options on this scales range from 0 (not at all) to 3 (severely). Higher scores indicate a higher risk of problem use. The total score of scale can vary between 0 to 63 . 
Table 1: Score and level of anxiety

\begin{tabular}{cc}
\hline SCORE & LEVEL \\
\hline $0-21$ & Low \\
$22-35$ & Average \\
$>36$ & High \\
\hline
\end{tabular}

\section{Result}

Table 1 shows demography descriptive statistics among students from two faculties in University Teknologi Mara (UiTM) Seremban. The results show out of all the 317 students, $32.8 \%$ or 104 students was male gender while $67.2 \%$ was female gender.

Table 1: Distribution of respondents by gender

\begin{tabular}{ccc}
\hline Gender & $\begin{array}{c}\text { Frequency } \\
\text { (n) }\end{array}$ & Percent (\%) \\
\hline Male & 104 & 32.8 \\
Female & 213 & 67.2 \\
\hline Total & 317 & 100.0 \\
\hline
\end{tabular}

Meanwhile table 2 shows $54.3 \%$ or 172 respondents are average age of $19-21$ years old, followed by respondents ages around $22-24$ years old is about $45.4 \%$ or 144 students and the last one $0.3 \%$ or only one respondent are average age of 25 years old and above.

Table 2: Distribution of respondents by age

\begin{tabular}{ccc}
\hline Age & Frequency (n) & Percent (\%) \\
\hline $19-21$ age & 172 & 54.3 \\
$22-24$ age & 144 & 45.4 \\
$\begin{array}{c}25 \text { age and } \\
\text { above }\end{array}$ & 1 & 0.3 \\
\hline Total & 317 & 100.0 \\
\hline
\end{tabular}

Table 3 illustrates the results the frequency and percentage of the use mobile phone. The finding of this study showed out of all the 317 students, $17.7 \%$ have low problem in using the mobile phone. $73.2 \%$ which stated the highest reading have medium problem use of mobile phone while the remaining $9.3 \%$ which stated the lowest percent have high problem use of mobile phone. There are five items that get highest mean score for problem in using the mobile phone, first is item seven which stated "I think I might be spending too much time using my cell phone" show highest mean score with reading 4.03 and follow by item five which stated "Previously I had the thought that it was not normal to spend time with a cell phone as I was doing" show second highest mean score with reading 3.55 .

Item 5 which stated "The time I spend using my cell phone makes me not do other more important work" show third highest mean score with reading 3.40. Item 1 which stated "When I use my cell phone less, I feel less satisfied" show forth highest mean score with reading 3.34 and lastly item 12 which stated "I use a cell phone even though I know I should do or homework" show forth highest mean score with reading 3.28 .

Table 3: Frequency and percentage of the use of mobile phone $(n=317)$

\begin{tabular}{ccc}
\hline Level & Frequency (n) & Percentage (\%) \\
\hline Low & 56 & 17.7 \\
Average & 232 & 73.2 \\
High & 29 & 9.1 \\
Total & 317 & 100.0 \\
\hline
\end{tabular}

Table 4 show among 317 students, high an anxiety records the lowest reading, which is $18.93 \%$. An average an anxiety records are $28.71 \%$ and the remaining $52.36 \%$ is the highest reading belongs to low anxiety.

Table 4: Frequency and percentage of anxiety level $(n=317)$.

\begin{tabular}{cccc}
\hline Level & Total & $\begin{array}{c}\text { Frequency } \\
(\mathbf{n})\end{array}$ & $\begin{array}{c}\text { Percentage } \\
(\mathbf{\%})\end{array}$ \\
\hline Low & $0-21$ & 166 & 52.36 \\
Average & $22-35$ & 91 & 28.71 \\
High & $>36$ & 60 & 18.93 \\
Total & & 317 & 100.00 \\
\hline
\end{tabular}


There are five items that get highest mean score for anxiety, first is item 5 which stated "Fearing bad things will happen" show highest mean score with reading 1.46 and follow by item 16 which stated "Scared to death" show second highest mean score with reading 1.32. Item 2 which stated "confused or a little dizzy" show third highest mean score with reading 1.30. Item 1 which stated "numbness or tingling sensation" show forth highest mean score with reading 1.23 and lastly item "The heart is pounding or beating fast" show fifth highest mean score with reading 1.19 .

According to table 5, Pearson correlation, $r=0.341(p=0.000<a 0.05)$, shows that there is significant relationship between the use of mobile phone and an anxiety among UiTM Seremban students. The relationship is weak and the positive coefficient means that the level use of mobile phone and level of an anxiety among students are directly proportional.

Table 5: Correlation between mobile phone problem use and anxiety level

\begin{tabular}{ccc}
\hline $\begin{array}{c}\text { Mobile Phone } \\
\text { Problem Use }\end{array}$ & $\begin{array}{c}\text { Mobile Phone } \\
\text { Problem Use }\end{array}$ & $\begin{array}{c}\text { Anxiety } \\
\text { Level }\end{array}$ \\
\hline & $\mathrm{R}$ & $\mathrm{p}$ \\
& 0.341 & 0.000 \\
\hline
\end{tabular}

\section{Discussion}

The university students focused on the present study was found that they have medium problem use of mobile phone. Majority of the students was agreed that they have spending too much time using my cell phone. This finding is consistent with earlier studies (Iqbal et al., 2017; Kuss et al., 2018; Muduli, 2014). The most plausible explanations for these findings are many university students are do not have flexible time to use mobile phone. This attitude makes them default and spent more time on their mobile phones. However, most of students aware that it was not normal to spend time with a cell phone because can affect their daily life. According Jyoti (2013) in their research found half of adults between 18 to 26 years old have spent time between 4 to 6 hours by using their mobile phone.

At the same time, majority students show the low level of an anxiety with mean score of 1.02. This finding is consistent with earlier studies by Ibrahim and Abdelreheem (2015); Inam, (2007) that shows student with low an anxiety is high followed by students with average anxiety. High in anxiety level shows the least students. In this research, many of students in UiTM Seremban are not influenced in a big problem and it give the reason their level of anxiety is low. Majority students a good time and daily life and social environment in their university.

An analysis between mobile phone use and an anxiety level among UiTM Seremban students shows Pearson correlation, $\mathrm{r}=$ 0.341 which means the relation between mobile phone problem use and an anxiety level is a weak relation according Guilford (1995) interpretation in correlation. The value $\mathrm{p}=0.000<\mathrm{a} 0.05$ (2-tailed) shows significant relationship between mobile phone problem use and an anxiety level among UiTM Seremban students.

This correlates with the research run by Kadir, Mehmet and Abdullah (2015) towards university students where the use of smart phone had positive correlation with an anxiety $r=0.276, p<0.001$. The similarity between their research and this research is the significant relation between mobile phone problem use and an anxiety level among UiTM Seremban students. The correlation value is the same between 0.20 to 0.40 . Research done by Jyoti (2013) had the same results where the higher level of mobile phone use, the higher level an anxiety. This shows level of mobile phone use and level of an anxiety are directly 
proportional. This showed similarity between their research and this research. Their research also shows if respondent use mobile phone for more than 6 hours, they will feel anxious.

\section{Conclusion}

Overall, mobile phone problem is use among students in UiTM Seremban are low and an anxiety level are also low. Thus, there are significant relationship between the use of mobile phone and an anxiety level although the relationship is weak. Mobile phone use has many advantages to students including to arranges their daily life and also to find some information of their study. The present study is not without its limitation. The finding is very specific and could only be generalized to population with the same characteristics. Despite the limitations, current study should provide the impetus for new investigations to refine the understanding of mobile phone use amongst private university students and government university students to generalize the large population. Further research could investigate other underlying factors that exist especially in their selfesteem and emotional intelligence.

\section{Acknowledgements}

The authors would like to thank a great appreciation as well to the Universiti Malaysia Terengganu for its support upon the completion of this research.

\section{References}

Cazzulino, F., Burke, R. V., Muller, V., Arbogast, H., \& Upperman, J. S. (2014). Cell phones and young drivers: a systematic review regarding the association between psychological factors and prevention. Traffic injury prevention, 15(3), 234-242.
Cheever, N. A., Rosen, L. D., Carrier, L. M., \& Chavez, A. (2014). Out of sight is not out of mind: The impact of restricting wireless mobile device use on anxiety levels among $1 \mathrm{o} \mathrm{w}$, moderate and high users. Computers in Human Behavior, 37, 290-297.

Demirci, K., Akgönül, M., \& Akpinar, A. (2015). Relationship of smartphone use severity with sleep quality, depression, and anxiety in university students. Journal of behavioral addictions, 4(2), 85-92.

El-Sayed Desouky, D., \& Abu-Zaid, H. (2020). Mobile phone use pattern and addiction in relation to depression and anxiety. East Mediterr Health J.

Ibrahim, M. B., \& Abdelreheem, M. H. (2015). Prevalence of anxiety and depression among medical and pharmaceutical students in Alexandria University. Alexandria Journal of Medicine, 51(2), 167-173.

Igarashi, T., Motoyoshi, T., Takai, J., \& Yoshida, T. (2008). No mobile, no life: Self- perception and textmessage dependency among Japanese high school students. Computers in Human Behavior, 24(5), 2311-2324.

Inam, S. B. (2007). Anxiety and depression among students of a medical college in Saudi Arabia. International journal of health sciences, 1(2), 295.

Iqbal, W. A. H. E. E. D., Khan, A. M., \& Khan, S. A. (2017). Problematic mobile phone among medical students using PUMP scale. Pakistan Journal of Medical \& Health Sciences, 11(3), 1-3.

Kardefelt-Winther, D. (2014). A conceptual and methodological critique of internet addiction research: Towards a model of compensatory internet use. Computers in Human Behavior, 31, 351-354. 
Kim, J. H., Seo, M., \& David, P. (2015). Alleviating depression only to become problematic mobile phone users: Can face-to-face communication be the antidote?. Computers in

Human Behavior, 51, 440-447.

Kuss, D. J., Kanjo, E., Crook-Rumsey, M., Kibowski, F., Wang, G. Y., \& Sumich, A. (2018). Problematic mobile phone use and addiction across generations: The roles of psychopathological symptoms and smartphone use. Journal of Technology in Behavioral Science, 3(3), 141149.

Long, J., Liu, T. Q., Liao, Y. H., Qi, C., He, H. Y., Chen, S. B., \& Billieux, J. (2016). Prevalence and correlates of problematic smartphone use in a large random sample of Chinese undergraduates. $B M C$ psychiatry, 16(1), 408.

Matsuda, M. (2000). Interpersonal relationships among young people and mobile phone usage: From attenuant to selective relationships. Japanese Journal of Social Informatics, 4(11), 111122.
Muduli, J. R. (2014). Addiction to technological gadgets and its impact on health and lifestyle: A study on college students (Doctoral dissertation).

Schroeder, B. L., Bailey, S. K., Whitmer, D. E., \& Sims, V. K. (2017, September). Measurement of technology behaviors: A look at texting scales. In Proceedings of the Human Factors and Ergonomics Society Annual Meeting (Vol. 61, No. 1, pp. 12081212). Sage CA: Los Angeles, CA: SAGE Publications.

Tavakol, M., \& Dennick, R. (2011). Making sense of Cronbach's alpha. International journal o $f$ medical education, 2, 53.

Vannucci, A., Flannery, K. M., \& Ohannessian, C. M. (2017). Social media use and anxiety i n emerging adults. Journal of affective disorders, 207, 163-166.

Widyanto, L., \& Griffiths, M. (2006). 'Internet addiction': a critical review. International Journal of mental health and Addiction, 4(1), 3151.

World Health Organization. (2002). The world health report 2002: reducing risks, promoting healthy life. World Health Organization 